\title{
Teachers' Perceptions of Students' Metacognitive Knowledge in Mathematics: A Case of Excellent Sports Talent Students
}

\author{
Yusep Cus Angkoso \\ Master Program of Mathematics \\ Education \\ Sebelas Maret University \\ Surakarta, Indonesia \\ joe_choose@yahoo.com
}

\author{
Dewi Retno Sari Saputro \\ Master Program of Mathematics \\ Education \\ Sebelas Maret University \\ Surakarta, Indonesia \\ dewi_rss@yahoo.com
}

\author{
Riyadi \\ Master Program of Mathematics \\ Education \\ Sebelas Maret University \\ Surakarta, Indonesia \\ yadi_laras@yahoo.com
}

\begin{abstract}
The aim of this study was to describe the teachers' understanding of their students' metacognitive knowledge. Four teachers who taught excellent sports talent students on Senior High School of Slogohimo, District of Wonogiri, Central Java, were asked to explain: (1) their understanding of their students' metacognitive knowledge; (2) how to evaluate their students' metacognitive knowledge; and (3) the obstacles in evaluated their students' metacognitive knowledge. The results showed that teachers were aware of students' metacognitive knowledge differences. Nevertheless, teachers assumed that the differences were directly proportional to the cognitive knowledge. As an effect, teachers never evaluated their students' metacognitive knowledge. The evaluations were just done to measure their students' understanding of mathematics concepts. Teachers also hadn't a good knowledge about evaluation instruments of metacognitive knowledge. The lack of teachers training about its also caused difficulties in designing the evaluation.
\end{abstract}

Keywords - metacognitive knowledge; mathematics; excellent sports talent students

\section{INTRODUCTION}

There are many Indonesian students who have excellent intelligence or talent in themselves. According to the Law of Indonesian Republic Number 20 the Year 2003, every student with excellent intelligence or talent has to get special education. The students require special education so that their excellent potency can be developed. A special education may facilitate the students to get achievements according to their potency.

Special education for students with excellent intelligence or talent has been held by several schools now, one of which is Senior High School of Slogohimo that located in Wonogiri District. The school realizes that Wonogiri has a lot of potencies for sports. To that end, this school organizes Excellent Sports Talent Program for excellent sports talent students.

Implementation of Excellent Sports Talent Program in Senior High School of Slogohimo so far can be said successful. Since its inception in 2010, the program has scored students that are able to excel in sports. Until now, these students have successfully provided many achievements for schools. In addition, many students from this program have the opportunity to continue their education in Higher Education through National Selection because of their achievements in sports.

Excellent sports talent students' achievements in the sports are certainly not apart from the role of a good sports coaching program. Each excellent sports talent student follows training session in accordance with his or her own sports branch. The training session is held four times a week outside school hours. Despite having a good positive impact on sports performance, these activities have the potential to interfere students' learning activities. Fatigue in training session will make a problem for students in learning. For that, teachers need to anticipate the problem by preparing appropriate to learn for excellent sports talent students.

The Excellent Sports Talent Program integrates the excellent sports talent students to learn together with regular students in a classroom at regular school. Consequently, the teachers had to work with characteristics differences of students [1]. On the other hand, the students have physical activities outside the classroom. It's may be related to academic performance [2] and [3]. The physical activities had positive relationship with cognitive function [4]. About mentality, the students, could control the emotion by replacing the negative thought with the positive thoughts [5]. Nevertheless, it can also give negative effect for their learning.

In the newest curriculum in Indonesia (i.e. Curriculum 2013), learning is emphasized on four aspects of the knowledge dimension, in addition to the dimensions of attitudes and skills. According to the Regulation of the Minister of Education and Culture Number 20 the Year 2016, the four aspects are factual, conceptual, procedural, and metacognitive knowledge. Metacognitive knowledge occupies the highest position compared with others in knowledge dimension.

Metacognitive knowledge means knowledge of a person about the own cognitive process and something that related to knowledge of information and relevant data [6]. Metacognitive knowledge includes the knowledge of how someone organizes, controls, and examines its own thinking processes [7]. The cognitive process will not be accomplished productively without metacognitive knowledge [8]. 
TABLE I. THE SUBJECTS

\begin{tabular}{|l|l|c|}
\hline \multicolumn{1}{|c|}{ Subject } & \multicolumn{1}{|c|}{ Education Background } & Certified \\
\hline STR & Master Degree & V \\
\hline SST & Bachelor Degree & - \\
\hline ENy & Bachelor Degree & - \\
\hline RRN & Bachelor Degree & - \\
\hline
\end{tabular}

\section{Data Collection and Data Analysis}

The data in this study were collected through interviewing the four subjects. The interviews were conducted to gather information about teachers' understanding that related to the metacognitive knowledge of excellent sports talent students in mathematics learning. The interviews were also done to obtain information that related to the teachers' evaluation of students' metacognitive knowledge. In addition, the interviews were also used to obtain information about the obstacles experienced by teachers in evaluating the metacognitive knowledge of students.

To collect data by interview, this study used interview guideline as reference to interview the subjects. The instrument is validating by expert judgment to make sure the validity. Then to make sure the validity of data, this study used the sources triangulation methods.

The data that have been collected through interviews was analyzed through several stages. These stages include data reduction, data presentation, and conclusions. First, data reduction was done to separate between useful data and useless data. Second, the data presentation was done by describing the data in the form of narrative text. Third, conclusions are made to obtain answers the research questions.

\section{RESULTS AND DISCUSSION}

The interviews had been conducted with four mathematics teachers that teach excellent sports talent students in Senior High School of Slogohimo. The results of the interviews are described as follows.

\section{A. Understanding of Students' Metacognitive Knowledge}

The teachers recognize that metacognitive knowledge is very important for students. According to the results of the interviews, metacognitive knowledge is an ability that must be possessed by excellent sport talent students. By good metacognitive knowledge, the students will be more easy to understand the mathematics concept. The students' metacognitive knowledge need to be developed through constructivism learning.

Teachers say that metacognitive knowledge is knowledge related to how students organize their cognitive knowledge. Concepts in mathematics will be understood by thinking deeply using their knowledge. The students' metacognitive knowledge will be better if they have good thinking ability.

The teachers also say that the metacognitive knowledge of excellent sport talent students is low. Excellent sport talent students are seen to have unconfident in learning mathematics. Excellent sport talent students tend to be less able to control their minds in learning mathematics. According to the teachers, excellent sport talent students easily give up when they find 
difficulty in learning mathematics concepts. The most of excellent sport talent students don't think more when they have difficulty to understand the concepts and to solve mathematics problems.

The teachers are aware that most of excellent sport talent students know about their low ability in mathematics. However, the students don't know the way to improve their ability. For that, the teachers always provide motivation for the students to always improve their learning activities.

\section{B. Evaluating the Students' Metacognitive Knowledge}

The interviews results indicate that teachers have difficulty in assessing the excellent sport talent students' metacognitive knowledge. The evaluation of the students' metacognitive knowledge is carried out simultaneously with the students' cognitive knowledge assessment. The teachers assume that the metacognitive knowledge of the students is in accordance with their cognitive knowledge.

The teachers assume that by assessing cognitive knowledge, metacognitive knowledge can also be evaluated. The students with good cognitive knowledge are also considered to have good metacognitive knowledge. The teachers assess the metacognitive knowledge of students based on test results of students' cognitive knowledge.

The teachers also do an evaluation of the students' metacognitive knowledge through observation when learning. The teachers see the students that are active in learning have better knowledge than passive. The students' activities are reflected in the activities of asking and expressing their ideas in understanding the concept of learning.

These results show that the teachers haven't done a specific evaluation of the students' metacognitive knowledge. The teachers also haven't developed a metacognitive knowledge evaluation instruments. The teachers also evaluate the students' metacognitive knowledge through observation in the learning process and through the tasks that finished by the students.

\section{Obstacles of Metacognitive Knowledge Evaluation}

From the results described before, the teachers haven't done a specific evaluation of the students' metacognitive knowledge. The teachers assume that evaluation can be done simultaneously with an evaluation of cognitive knowledge. This suggests that the teachers have difficulties in evaluating the students' metacognitive knowledge.

The interviews results indicate that the teachers have difficulties to evaluate the students' metacognitive knowledge. It's caused by several things. The teachers claim that they haven't good ability in arranging metacognitive knowledge evaluation instrument. Before the Curriculum 2013 was used, the previous curriculum didn't involve the metacognitive knowledge as a learning goal. It makes difficulties for the teachers to develop evaluation instruments.

The training that teachers have followed related to the implementation of Curriculum 2013 also specifically does not train teachers to design lessons based on metacognitive knowledge. Likewise in the evaluation, teachers only practice to evaluating students' cognitive (factual, conceptual, and procedural) knowledge, attitudes, and skills. The teachers claim to require training that specifically focusing to the evaluation ability of metacognitive knowledge.

\section{CONCLUSION}

The results and discussions that have been described previously conclude the teachers assume that the metacognitive knowledge of excellent sports talent students is relatively low. The evaluation of students' metacognitive knowledge hasn't been done specifically. The teachers evaluate the metacognitive knowledge based on the cognitive knowledge assessment results. It means the teachers assume that the metacognitive knowledge is directly proportional to the cognitive knowledge.

Based on the results, this study also concludes that the teachers have difficulties to prepare the metacognitive knowledge evaluation instruments. The training of specific metacognitive knowledge evaluation instruments development hasn't been done. The change of curriculum also makes the teachers have little understanding of the way to do metacognitive knowledge evaluation. It's caused of the previous curriculum didn't involve metacognitive knowledge as a learning goal.

Based on these conclusions, the future researchers are expected to do research about the development of metacognitive knowledge evaluation instruments. In addition, the researchers are also expected to develop learning models based on metacognitive knowledge by regarding students' special intelligence or talents.

\section{REFERENCES}

[1] S. Bubpha, P. Erawan, and P. Saihong P, "Inclusion: The practice of inclusive education-case study of best practices in the united states," European Journal Off Social Sciences, vol. 37, pp. 149-159, 2013.

[2] K. Berg, K, "Justifying physical education based on neuroscience evidence," Journal of Phy. Edu. Rec. and Dance, vol. 81, pp. 24-46, 2010.

[3] S. Sauer, S. Desmond, and M. Heintzelman, "Beyond the playing field: The role of athletic participation in early career success," Personnel Review, vol. 42, pp. 644-661, 2013.

[4] B. A. Sibley and J. L. Etnier, "The relationship between physical activity and cognition in children: A meta-analysis," Pediatric Exercise Science, vol. 15 , pp. 243-256, 2003.

[5] L. Crust and K. Azadi, "Mental toughness and athletes' use of psychological strategies," European Journal of Sport Science, vol. 10, pp. 43-51, 2010.

[6] E. Suherman, Common Text Book: Strategi Pembelajaran Matematika Kontemporer. Bandung: JICA-Universitas Pendidikan Indonesia (UPI), 2003.

[7] Syahmani and D. C. F. U. Borneo, "The differences of students learning outcomes and metacognitive skills by using PBL and metacognitivePBL," Adv. in Soc. Sci., Edu. and Hum. Research, vol. 100, pp. 249-255, 2017 [Proceeding 5th South East Asia Development Research (SEA-DR) International Conference]

[8] A. Kuzle, "Patterns of metacognitive behavior during mathematics problem-solving in a dynamic geometry environment," IEJME Math. Education, vol. 8, no. 1, pp. 20-40, 2013

[9] S. Sengul and Y. Katranci, "Metacognitive aspects of solving function problems," Proc. Soc. and Beh. Sciences, vol. 46, pp. 2178-2182, 2012.

[10] J. A. Shahbari, W. Daher, and S. Rasslan, "Mathematical knowledge and the cognitive and metacognitive processes emerged in model-eliciting activities," Int. Jou. on New Trends in Edu. and Their Implications, vol. no. 2 , pp. $209-219,2014$. 